\title{
Growth of Spondias tuberosa Irrigated With Saline Water
}

\author{
F. S. Matos ${ }^{1}$, I. A. S. Freitas ${ }^{1}$, V. L. G. Pereira ${ }^{1}$, L. P. Borges ${ }^{1}$, W. K. L. Pires ${ }^{1}$, M. C. H. Souza ${ }^{1}$, G. H. F. de Lima ${ }^{1}$ \\ \& V. A. Amorim ${ }^{1}$ \\ ${ }^{1}$ Research Group on Physiology of Vegetable Production, University of Goiás, Ipameri, GO, Brazil \\ Correspondence: F. S. Matos, Research Group on Physiology of Vegetable Production, University of Goiás, \\ Ipameri, GO, Brazil. E-mail: fabio.agronomia@hotmail.com
}

Received: November 18, 2018

Accepted: December 21, 2018

Online Published: February 15, 2019

doi:10.5539/jas.v11n3p320

URL: https://doi.org/10.5539/jas.v11n3p320

\begin{abstract}
Spondias tuberosa is a fruit tree species and its production is exploited by extractivism. The expansion of the planted area may be favored by using irrigation with saline water. Thus the objective of the present study was to assess the initial growth of $S$. tuberosa plants irrigated with saline water. The study was carried out in $12 \mathrm{~L}$ pots containing substrate composed of oxisol, sand and manure at 3:1:0.5. Respectively, in a greenhouse at the State University of Goiás, Campus Ipameri, Brazil. A completely randomized design was used with five treatments and six replications consisting of $S$. tuberosa plants irrigated with water with electric conductivity of $0 \mathrm{dS} \mathrm{m}^{-1} ; 2$ $\mathrm{dS} \mathrm{m} \mathrm{m}^{-1} ; 4 \mathrm{dS} \mathrm{m}^{-1} ; 6 \mathrm{dS} \mathrm{m}^{-1}$ and $8 \mathrm{dS} \mathrm{m}^{-1}$ for 40 days. The growth of the $S$. tuberosa plants was significantly affected by the salinity of the irrigation water. The plants did not show visible symptoms of toxicity but the saline conditions were enough to reduce the start of new leaves and growth as a whole. The expressive effect of salinity on dehydration of $S$. tuberosa plants, manifested by the low relative water content, transpiration and accentuated leaf fall, indicated that using saline water on $S$. tuberosa plants at the initial growth stage may result in significant delay in development and may influence the adult plant.
\end{abstract}

Keywords: caatinga, cerrado, electric condutivity, Spondias tuberosa

\section{Introduction}

Brazil is the third fruit producer in the world, second only to China and India. The Brazil especially for directly fruit production and juice and nectar industrialization and export. The Brazilian fruit cropping sector is important socially and economically because it employs about 5 million people, $16 \%$ of the total of jobs in agribusiness (ABF, 2018). The continental extension allows cropping of different native and/or domesticated fruit species, but in spite of the positive numbers, the segment could generate more wealth by exploiting commercially native species of Spondias tuberosa (locally known as imbu) (Nunes et al., 2018).

The $S$. tuberosa is a fruit much appreciated in markets in several states and consumed directly in the natural or processed form "umbuzada", sweets, preserves and ice cream, and has attracted the interest of fruit pulp processing industries and generated income for family agriculture (Rodorff et al., 2018). The demand for the fruit is large and it is consumed in several states of Brazil and also reaches market niches in Europe (Lima, Silva, \& Oliveira, 2018), however, production is obtained extractivistically in native plants. Generating basic agronomic information can encourage commercial plantings and increase the profitability of several families.

The $S$. tuberosa is a plant tree belonging to the family Anacardiaceae, native to the semiarid regions of the Brazilian Northeast, and is found throughout the drought polygon in Brazil (Lima et al., 2018). It develops well in regions with low rainfall, ranging from 400 to $800 \mathrm{~mm}$. It is a tree approximately $7 \mathrm{~m}$ tall and the canopy is up to $12 \mathrm{~m}$ in diameter. The plant is xerophile and deciduous, adapted to heat and soils with different fertility levels and agricultural suitability (Mertens et al., 2017; Paula et al., 2012).

The $S$. tuberosa plant has an important water storage structure, the xylopodium, that consists of a woody tuber important for the species to overcome the dry period (Lins Neto et al., 2010). Furthermore, the plants loose leaves during the dry period and minimize leaf transpiration. In spite of its drought tolerance it is coherent to state that yield is increased with adequate water availability (Antunes et al., 2016). Brazil has potential and perspective to double the irrigated area by 2026 (Irrigo, 2017).

The expansion of the planted area will certainly coincide with the development of technologies that ensure profitable yield and the use of irrigation may represent a fundamental practice for the agricultural success of the 
S. tuberosa, but the frequency of reservoirs with low quality water should be taken into consideration when setting up the orchard. Irrigation with saline water is the reality in semiarid regions where quality water is not available for agriculture (Lopes, Lima, \& Klar, 2012). Salinity causes drop in crop yields due to the osmotic, toxic and/or nutritional effects (Negrão Schmöckel, \& Tester, 2017; Zörb, Geilfus, \& Dietz, 2018). According to Shannon and Grieve (1998), water electric conductivity equal or greater than $4 \mathrm{dS} \mathrm{m}^{-1}$ drastically reduces plant growth. However, electric conductivity less than $4 \mathrm{dS} \mathrm{m}^{-1}$ may not cause significant negative effects.

Adopting new management practices may be an important alternative in the setting up and conducting of new orchards and alter the present scenario a few commercial plantations with production obtained almost exclusively by extractivism (Costa et al., 2015). The main difficulties found for setting up commercial $S$. tuberosa plantations include little agronomic knowledge of the species, elucidation of the initial seedling growth and the extensive juvenile period. The need to adopt innovative management practices in order to contribute to the generation of knowledge and boost the interest in commercial crops of the umbuzeiro crop is of fundamental importance. The present study aimed to evaluate the initial growth of umbuzeiro plants irrigated with saline water.

\section{Material and Methods}

\subsection{General Information}

The study was carried out at the State University of Goiás, Campus Ipameri, Brazil, 17 $43^{\prime} 19^{\prime \prime}$ latitude south and $48^{\circ} 09^{\prime} 35^{\prime \prime}$ longitude west, altitude $764 \mathrm{~m}$. This region has a tropical climate with a dry winter and wet summer (Aw) according to the Köppen classification. The average temperature of this region is $20{ }^{\circ} \mathrm{C}$ (Alvares et al., 2013). The seeds were sown in $12 \mathrm{~L}$ pots on a bench in a greenhouse covered with transparent plastic and the sides had shading screening that intercepted $50 \%$ of the solar radiation.

The seedlings were produced using mechanically scarified seeds and placed to germinate on sand. At 10 days after emergence (DAE) they were selected and transplanted to nursery beds. At 60 DAE they were transplanted to polyethylene pots containing substrate consisting of red-yellow latosol, sand and manure at 3:1:0.5, respectively. After chemical analysis of the soil, liming and fertilizer were carried out according to recommendations by Cruz, Andrade, and Feitosa (2016).

\subsection{Experimental Design}

The experiment was set up in a completely randomized design with five treatments and six replications consisting of 250-day-old Spondias tuberosa plants irrigated with water with electric conductivity of $0 \mathrm{dS} \mathrm{m}^{-1} ; 2$ $\mathrm{dS} \mathrm{m} \mathrm{m}^{-1} ; 4 \mathrm{dS} \mathrm{m}^{-1} ; 6 \mathrm{dS} \mathrm{m}^{-1}$ and $8 \mathrm{dS} \mathrm{m}^{-1}$ for 40 days. The electric conductivity levels of the irrigation water were obtained using $\mathrm{NaCl}$ and measured by a bench conductivity meter. The seedlings were irrigated daily and the volume of water was determined by the difference in the mass of the pots based on the substrate water retention capacity as described by Sá et al. (2017). The following analyses were carried out forty days after the start of the treatments: plant height, stem diameter, number of leaves, total biomass, total transpiration, relative water content and leaf sodium concenration.

\subsection{Growth Variables}

Plant height was measured from the root-stem transition region at soil level (crown) to the tip of the stem using a graded rule. The stem diameter was measured at the crown with a digital pachymeter. The number of leaves was obtained by counting. The leaf area and root area were determined using the equipment LI-3100 Area Meter, LI-COR, USA. The destructive analyses were made with the roots, xylopodiums, stems and leaves separated and placed in a chamber at $72{ }^{\circ} \mathrm{C}$ to dry until they reached constant dry matter and were weighed. The dry matter data were used to calculate the root mass ratio (RMR), stem mass ratio (RMC), leaf mass ratio (RMF) and total biomass.

\subsection{Transpiration}

The total daily transpiration of the plant was determined from the difference in the mass of the pots. The set of pots with plants were placed in individual plastic bags fixed with a rubber band at the stem of the plant, leaving the canopy (leaves and stem) exposed. The pots were weighed at 12 o'clock (mass 01 ) and again 24 hours later (mass 02). The total transpiration was estimated based on the difference between mass 01 and mass 02 (Dos Anjos et al., 2017). 


\subsection{Relative Water Content (TRA)}

To obtain the relative water content, ten $12 \mathrm{~mm}$ leaf discs were removed, weighed and placed for four hours to saturate in petri dishes with distilled water. The discs were again weighed and placed to dry at $70{ }^{\circ} \mathrm{C}$ for $72 \mathrm{~h}$ to obtain the dry matter weight.

\subsection{Photosynthetic Pigments}

To determine the total chlorophylls and carotenoids concentrations, $0.6 \mathrm{~mm}$ diameter leaf discs were removed from completely opened leaves and placed in test tubes containing dimethyl sulfoxide (DMSO). Then extraction was carried out in a water bath at $65^{\circ} \mathrm{C}$ for one hour. Aliquots were removed for spectrophotometric reading at 480,646 and $665 \mathrm{~nm}$. The contents of chlorophyll a $(\mathrm{Cl} a)$, chlorophyll b $(\mathrm{Cl} b)$ and total carotenoids (Car) were determined according to the equation proposed by Wellburn (1994).

\subsection{Sodium and Calcium Leaf Concentrations}

The sodium and calcium leaf concentrations were determined by removing three folioles from the third pair of completely opened leaves and squashed in $5 \mathrm{~mL}$ distilled water in a pestle and mortar and aliquotes were removed from the solution obtained for reading in a portable sodium analyzer (LAQUAtwin) and the values were obtained in parts per million (ppm).

\subsection{Statistical Procedures}

An analysis of variance and a linear and quadratic regression were performed and in the cases of significance of regression by the $\mathrm{F}$ test, the coefficient of determination $\left(\mathrm{R}^{2}\right)$ was calculated by the ratio of the sum of the squares of the regression over the total sum of squares. Multivariate analysis was carried out using principal component analysis in an analysis of multivariate permutational variance (PERMANOVA) (Anderson, 2001). The statistical analysis and the regression graphs were performed using the softwares R 3.4 (R Core Team, 2018) and SigmaPlot 10.0 (Systat Software, 2006).

\section{Results and Discussion}

Table 1 shows the summary of the analysis of variance and significance of regression for stem diameter, leaf area, plant height, transpiration, total biomass, number of leaves and root area. All the variables analyzed presented significant differences at $5 \%$ probability by the $\mathrm{F}$ test and the lowest values were obtained in plants irrigated with water with higher electric conductivity. Only the leaf area and the root system area did not fit the linear and quadratic regression models.

Table 1. Summary of analysis of variance and mean test in $S$. tuberosa plants cultivated under different electrical conductivities $\left(0 ; 2 ; 4 ; 6 ; 8 \mathrm{dS} \mathrm{m}^{-1}\right)$

\begin{tabular}{|c|c|c|c|c|c|c|c|c|}
\hline \multirow{2}{*}{ Source of variation } & \multirow{2}{*}{$\mathrm{DF}$} & \multicolumn{7}{|c|}{ Mean square } \\
\hline & & $\mathrm{SD}$ & LA & $\mathrm{PH}$ & $E$ & $\mathrm{~PB}$ & $\mathrm{NF}$ & $\mathrm{AR}$ \\
\hline Doses & 4 & $12.9^{*}$ & $3.88^{*}$ & $1233.1^{*}$ & 55.99* & $0.30 *$ & 0.40 & $0.76^{*}$ \\
\hline Error & 25 & 3.37 & 1.39 & 460.10 & 18.14 & 0.15 & 0.30 & 0.22 \\
\hline \multirow[t]{2}{*}{$\mathrm{CV}(\%)$} & & 11.17 & 24.37 & 17.88 & 13.60 & 10.96 & 23.32 & 16.86 \\
\hline & & \multicolumn{7}{|c|}{ Regression Analysis } \\
\hline Linear & & $*$ & ns & $*$ & $*$ & $*$ & $*$ & ns \\
\hline Quadratic & & ns & ns & ns & ns & ns & ns & ns \\
\hline
\end{tabular}

Note. $\mathrm{SD}=$ stem diameter; $\mathrm{LA}=$ leaf area; $\mathrm{PH}=$ plant height; $\mathrm{E}=$ transpiration; $\mathrm{PB}=$ plant biomass; $\mathrm{NF}=$ number of leaves; $\mathrm{AR}=$ area of the root. ${ }^{* *}$ significant at $1 \%$ probability and $*$ significant at $5 \%$ probability by the $\mathrm{F}$ test.

Table 2 shows the summary of the analysis of variance and significance of the regression for sodium and calcium content, leaf mass ratio, stem mass ratio, root mass ratio, carotenoids, total chlorophyll and relative water content. Only sodium content and relative water content presented significant difference by the $\mathrm{F}$ test and fitted the linear regression model. 
Table 2. Summary of analysis of variance and mean test in plants of Spondias tuberosa cultivated under different electrical conductivities $\left(0 ; 2 ; 4 ; 6 ; 8 \mathrm{dS} \mathrm{m}^{-1}\right)$

\begin{tabular}{|c|c|c|c|c|c|c|c|c|c|}
\hline \multirow{2}{*}{ Source of variation } & \multirow{2}{*}{$\mathrm{DF}$} & \multicolumn{8}{|c|}{ Mean square } \\
\hline & & $\mathrm{Na}$ & $\mathrm{Ca}$ & LMR & SMR & RMR & Car & Chl $a+b$ & RWC \\
\hline Doses & 4 & $1.88 *$ & $2318.61^{\mathrm{ns}}$ & $0.002^{\mathrm{ns}}$ & $0.002^{\mathrm{ns}}$ & $0.001^{\mathrm{ns}}$ & $0.25^{\mathrm{ns}}$ & $2.28^{\mathrm{ns}}$ & $0.54^{*}$ \\
\hline Error & 25 & 1.26 & 484.60 & 0.002 & 0.001 & 0.001 & 0.39 & 2.59 & 0.34 \\
\hline \multirow[t]{2}{*}{$\mathrm{CV}(\%)$} & & 22.18 & 30.56 & 24.95 & 8.92 & 8.80 & 37.06 & 23.47 & 23.76 \\
\hline & & \multicolumn{8}{|c|}{ Regression Analysis } \\
\hline Linear & & $*$ & ns & ns & ns & ns & ns & ns & $*$ \\
\hline Quadratic & & ns & ns & ns & ns & ns & ns & ns & ns \\
\hline
\end{tabular}

Note. $\mathrm{Na}=$ sodium; $\mathrm{Ca}=$ calcium; $\mathrm{LMR}=$ leaf mass ratio; $\mathrm{SMR}=$ stem mass ratio; $\mathrm{RMR}=$ root mass ratio; Car $=$ carotenoids; $\mathrm{Chl} \mathrm{a}+\mathrm{b}=$ total chlorophyll; $\mathrm{RWC}=$ relative water content. $* *$ significant at $1 \%$ probability and * significant at $5 \%$ probability by the $\mathrm{F}$ test.

Plant height, biomass, number of leaves, stem diameter, transpiration, and relative water content presented decreasing linear fit as the electric conductivity increased, as shown in Figure 1. S. tuberosa plant growth was significantly affected by the salinity of the irrigation water. The plants did not present visual symptoms of toxicity but the data showed a marked effect of the solutes in reducing the water potential and consequently less soil solution absorption at a magnitude sufficient to reduce the start and growth as a whole, manifested in the reduced biomass under severe saline conditions. According to Santos et al. (2018) the start and development of the first leaf depend on the water status of the plant. Reduction in water absorption promotes alteration in the formation and development of new leaves.

The reduction in transpiration and relative water content indicated that the $S$. tuberosa plants had difficulty in absorbing water due to the low water potentials because of the salinity of the irrigation water. Water loss is minimized at the cost of stomata closure and concomitantly by limiting $\mathrm{CO}_{2}$ inflow, assimilate production and biomass accumulation. Reduction in biomass accumulation under saline stress conditions is common in several species and is an important survival mechanism, because bigger biomass requires higher energetic expenditure to preserve the cell metabolism (Souza et al., 2015).

Reduction in the number of leaves minimizes water loss by transpiration and allows the plant to delay and guarantee immediate survival. However, in the present study, it was observed that the tolerance of the S. tuberosa to drought was not associated with maintained hydration, but possibly to protoplasmatic tolerance because it is an anhydrous plant that does not maintain a stable water content in the period of water limitation.

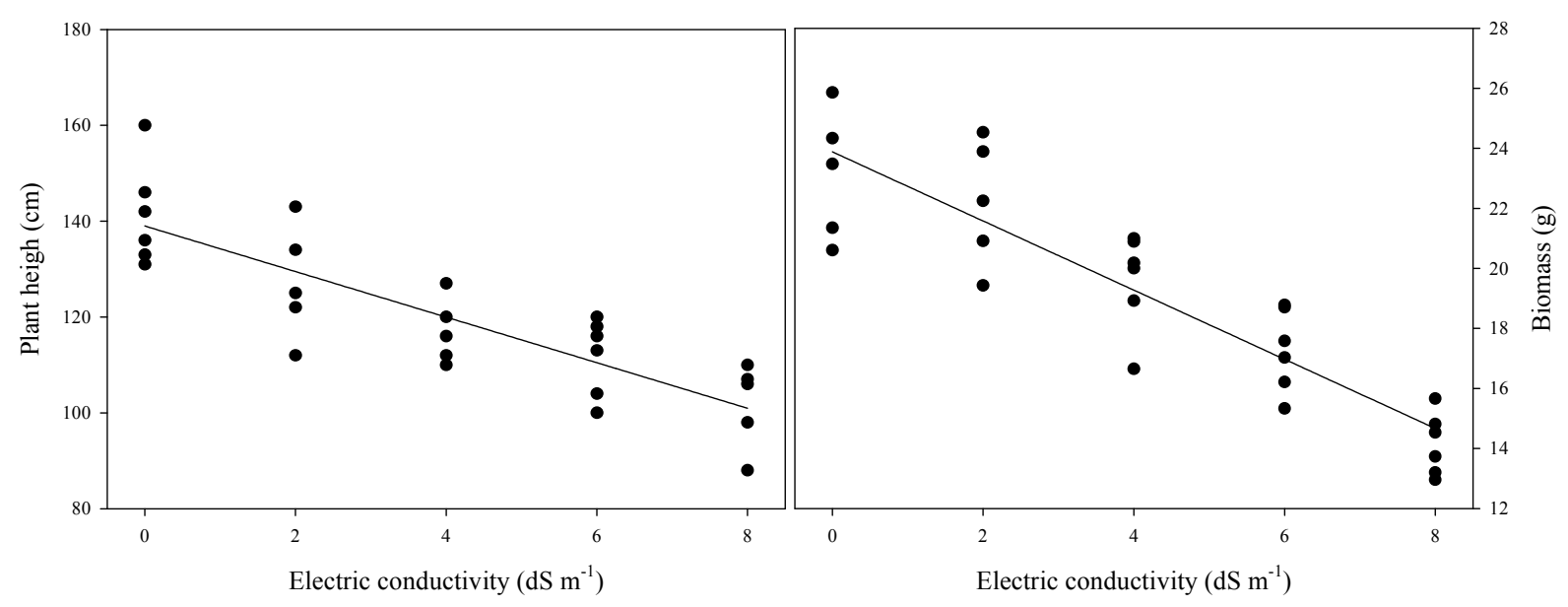



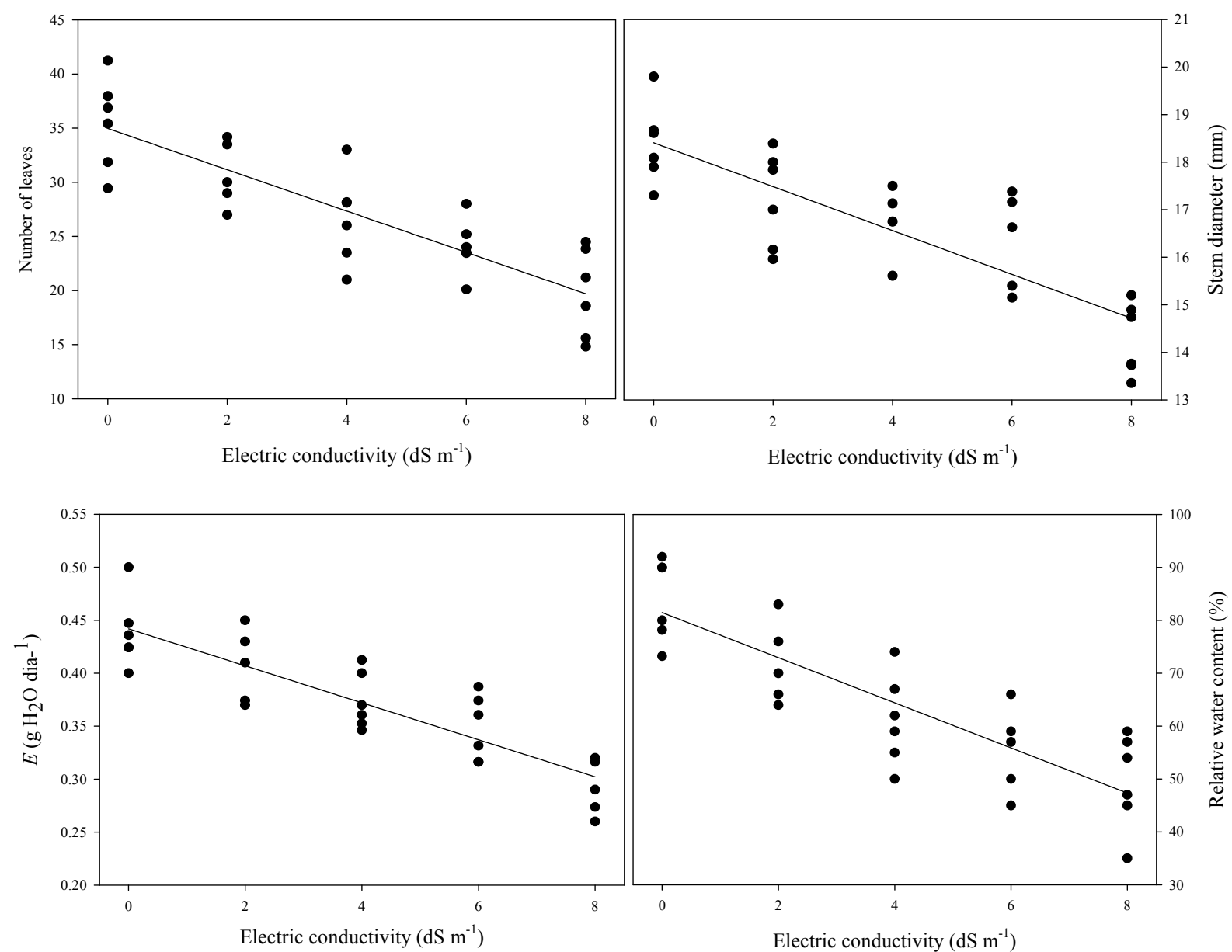

Figure 1. Regression equations for plant height $\left(\mathrm{Y}=139.00-4.7547 \mathrm{x}, \mathrm{R}^{2}=0.70 * *\right)$, stem diameter $(\mathrm{Y}=$ $\left.18.4085-0.4616 \mathrm{x}, \mathrm{R}^{2}=0.70 * *\right)$, number of leaves $\left(\mathrm{Y}=34.9725-1.9082 \mathrm{x}, \mathrm{R}^{2}=0.71 * *\right)$, plant biomass $(\mathrm{Y}=$ $\left.23.8820-1.1517 \mathrm{x}, \mathrm{R}^{2}=0.80^{* *}\right)$, transpiration $\left(\mathrm{Y}=0.4419-0.0175 \mathrm{x}, \mathrm{R}^{2}=0.75^{* *}\right)$ and relative water content $\left(\mathrm{Y}=81.4656-4.2649 \mathrm{x}, \mathrm{R}^{2}=0.71^{* *}\right)$ of $S$. tuberosa plants irrigated with water with different electric condutivity $\left(0 ; 2 ; 4 ; 6 ; 8 \mathrm{dS} \mathrm{m}^{-1}\right)$

Note. $* *$ significant at $1 \%$ probability by the $\mathrm{F}$ test.

The principal components analysis and sodium content in the S. tuberosa leaves are shown in Figura 2. The principal component analysis aggregated $88 \%$ of the variables of the data on axes I and II. Two groups were formed and the determining variables were leaf area and root area. The first group consisted of plants irrigated with zero electric conductivity, to the left of axis 1 while the second group was formed by the plants irrigated with water with $2 \mathrm{dS} \mathrm{m}^{-1}$ to $8 \mathrm{dS} \mathrm{m}^{-1}$ electric conductivity to the right of axis 1 . These results indicated that the growth of $S$. tuberosa plants at the initial development stages presented sensitivity to salinity with visual symptoms of leaf fall.

The increasing linear fit of the regression to the sodium content with the increase in electric conductivity of the irrigation water indicated that the $S$. tuberosa plants did not use mechanisms that included or minimized sodium absorption. According to Dos Anjos et al. (2017) activation of $\mathrm{H}^{+}$-ATPase of the root plasmatic membrane helps to reduce sodium absorption by alterations in the calcium cytosolic concentration. Absence of differences in calcium leaf concentrations indicated that the $\mathrm{Ca}^{2+}$ did not activate the sodium detoxification mechanism present in the plasmatic membrane as reported by Taiz et al. (2017). In addition, it is pointed out that the increase in leaf sodium content did not present visual symptoms or influence the photosynthetic pigment concentration, and therefore, appears not to have been toxic. Thus the plant may have compartmentalized the sodium in the vacuole as a means of protecting the photosynthetic machinery. 


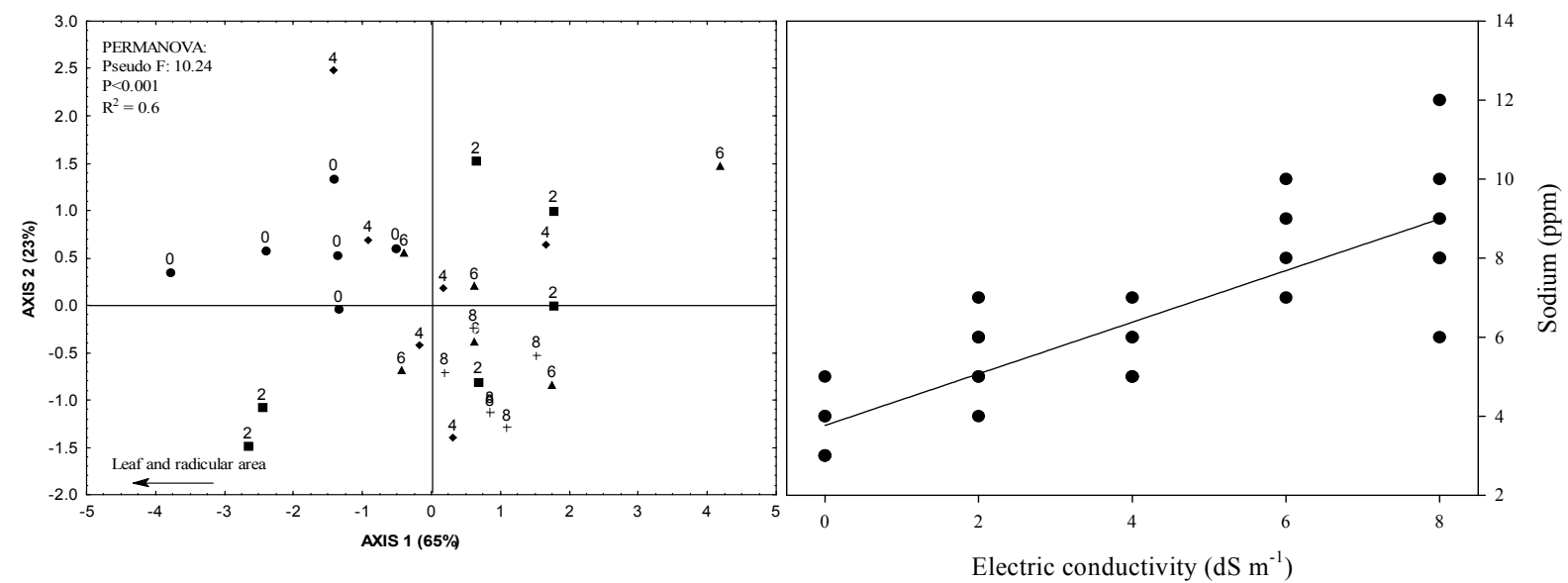

Figure 2. Principal Component Analysis and Regression Equation for Sodium $\left(\mathrm{Y}=3.7667+0.6531 \mathrm{x}, \mathrm{R}^{2}=\right.$ $\left.0.70^{* *}\right)$ in $S$. tuberosa plants irrigated with water with different electrical conductivities $\left(0 ; 2 ; 4 ; 6 ; 8 \mathrm{dS} \mathrm{m}{ }^{-1}\right)$.

The arrows indicate the directions in which the variables increase in relation to the axis

Note. ** significant at $1 \%$ probability by $\mathrm{F}$ test.

The significant growth reduction, specifically in biomass accumulation and the expressive effect of the salinity on dehydration of $S$. tuberosa plants manifested by the low relative water content, transpiration and accentuated leaf fall indicated that saline water should be used with caution on S. tuberosa plants at the initial growth stage, because the plant may present significant delay in development that may influence the adult plant.

\section{Conclusions}

The $S$. tuberosa plants at the initial stage of development were sensitive to salinity.

The use of saline water reduced the plant growth of $S$. tuberosa plants and may damage adult plant development.

\section{References}

Alvares, C. A., Stape, J. L., Sentelhas, P. C., Gonçalves, J. L. M., \& Sparovek, G. (2013). Köppen’s climate classification map for Brazil. Meteorologische Zeitschrift, 22(6), 711-728. https://doi.org/10.1127/0941-29 48/2013/0507

Anderson, M. J. (2001). A new method for non-parametric multivariate analysis of variance. Austral Ecology, 26, 32-46. https://doi.org/10.1111/j.1442-9993.2001.01070.pp.x

Antunes, W. C., Mendes, K. R., Chaves, A. R. M., Ometto, J. P., Jarma-Orozco, A., \& Pompelli, M. F. (2016). Spondias tuberosa trees grown in tropical, wet environments are more susceptible to drought than those grown in arid environments. Revista Colombiana de Ciências Hortícolas, 10(1), 9-27.

ABF (Anuário Brasileiro de Fruticultura). (2018). Santa Cruz do Sul: Editora Gazeta (p. 88).

IRRIGO (Associação do Irrigantes do Estado de Goiás). (2017). Retrieved from https://www.irrigoias.com. br/single-post/Brasil-pode-dobrar-area-irrigada-ate-2026-e-se-tornar-um-gigante-mundial-da-producao-dealimentos

Costa, F. R., Rêgo, E. R., Rêgo, M. M., Neder, D. G., Silva, S. M., \& Schunemann, A. P. P. (2015). Análise biométrica de frutos de umbuzeiro do semiárido Brasileiro. Bioscience Journal, 31(3), 682-690. https://doi.org/10.14393/BJ-v31n3a2015-22844

Cruz, F. R. S., Andrade, L. A. de, \& Feitosa, R. C. (2016). Produção de mudas de umbuzeiro (Spondias tuberosa Arruda Câmara) em diferentes substratos e tamanho de recipientes. Ciência Florestal, 26(1), 69-80. https://doi.org/10.5902/1980509821092

Dos Anjos, R. A. R., Santos, L. C. S., Oliveira, D. B., Amaro, C. L., Rios, J. M., Rocha, G. T... \& Matos, F. S. (2017). Initial growth of Jatropha curcas plants subjected to drought stress and silicon (Si) fertilization. Australian Journal of Crop Science, 11(4), 479-484. https://doi.org/10.21475/ajcs.17.11.04.377

Lima, M. A. C., Silva, S. M., \& Oliveira, V. R. (2018). Umbu-Spondias tuberosa. Exotic Fruits, $427-433$. https://doi.org/10.1016/B978-0-12-803138-4.00057-5 
Lins Neto, E. M. F., Peroni, N., \& Albuquerque, U. P. (2010). Traditional knowledge and management of umbu (Spondias tuberosa, Anacardiaceae): An endemic species from the semi-arid region of northeastern Brazil. Economic Botany, 64(1), 11-21. https://doi.org/10.1007/s12231-009-9106-3

Lopes, C. T., Lima, K. B., \& Klar, A. E. (2012). Desenvolvimento inicial de plantas de eucalyptus platyphylla submetidas a níveis de salinidade. Irriga, 17(4), 494-500. https://doi.org/10.15809/irriga.2012v17n4p494

Mertens, J., Germer, J., Siqueira Filho, J. A., \& Sauerborn, J. (2017). Spondias tuberosa Arruda (Anacardiaceae), a threatened tree of the Brazilian Caatinga? Brazilian Journal of Biology, 77(3), 542-552. https://doi.org/ 10.1590/1519-6984.18715

Negrão, S., Schmöckel, S. M., \& Tester, M. (2017). Evaluating physiological responses of plants to salinity stress. Annals of Botany, 119(1), 1-11. https://doi.org/10.1093/aob/mcw191

Nunes, E. N., Guerra, N. M., Arévalo-Marín, E., Alves, C. A. B., Do Nascimento, V. T., Da Cruz, D. D., ... De Lucena, R. F. (2018). Local botanical knowledge of native food plants in the semiarid region of Brazil. Journal of Ethnobiology and Ethnomedicine, 14(1), 49-62. https://doi.org/10.1186/s13002-018-0249-0

Paula, B. de, Carvalho Filho, C. D., Matta, V. M. da, Menezes, J. da S., Lima, P. da C., Pinto, C. O., \& Conceição, L. E. M. G. (2012). Produção e caracterização físico-química de fermentado de umbu. Ciência Rural, 42(9), 1688-1693. https://doi.org/10.1590/S0103-84782012000900027

R Core Team. (2018). R: A language and environmental for statistical computing. Vienna, Austria. Retrieved from http://www.R-project.org

Rodorff, V., Steinmetz, L., Mertens, J., Siegmund-Schultze, M., \& Köppel, J. (2018). Applying Bayesian networks to evaluate small-scale farmers' perceptions of native reforestation practices in Brazil's Caatinga biome. Regional Environmental Change, 18(7), 1983-1997. https://doi.org/10.1007/s10113-018-1370-2

Sá, F. V. S., Mesquita, E. F., Souza, F. M., Mesquita, S. O., Paiva, E. P., \& Silva, A. M. (2017). Depleção de água e composição do substrato na produção de mudas de melancia. Revista Brasileira de Agricultura Irrigada, 11(3), 1398-1406. https://doi.org/10.7127/rbai.v11n300550

Santos, E. F., Araújo, R. R., Lemos, E. E. P., \& Endre, L. (2018). Quantificação de compostos bioativos em frutos de umbu (Spondias tuberosa Arr. Câm.) e Cajá (Spondias mombin L.) nativos de alagoas. Ciência Agricola, 16(1), 21-29. https://doi.org/10.28998/rca.v16i1.3484

Shannon, M. C., \& Grieve, C. M. (1998). Tolerance of vegetable crops to salinity. Scientia Horticulturae, 78(1-4), 5-38. https://doi.org/10.1016/S0304-4238(98)00189-7

Souza, B. R., Freitas, I. A. S., Lopes, V. A., Rosa, V. R., \& Matos, F. S. (2015). Growth of eucalyptus plants irrigated with saline water. African Journal of Agricultural, 10(10), 191-196. https://doi.org/10.5897/AJAR 2014.9087

Systat Software. (2006). SigmaPlot for Windows, Version 10.0. San Jose: Systat Software.

Taiz, L., Zeiger, E., Moller, I. M., \& Murphy, A. (2017). Fisiologia Vegetal (6th ed.). Porto Alegre: Artmed.

Wellburn, A. R. (1994). The spectral determination of chlorophylls a and b, as well as total carotenoids, using various solvents with spectrophotometers of different resolution. Journal of Plant Physiology, 144(3), 307-313. https://doi.org/10.1016/S0176-1617(11)81192-2

Zörb, C., Geilfus, C.-M., \& Dietz, K.-J. (2018). Salinity and crop yield. Plant Biology. https://doi.org/10.1111/ plb. 12884

\section{Copyrights}

Copyright for this article is retained by the author(s), with first publication rights granted to the journal.

This is an open-access article distributed under the terms and conditions of the Creative Commons Attribution license (http://creativecommons.org/licenses/by/4.0/). 